\title{
Undeserving Welfare Recipients from the State's Point of View in Québec, Canada
}

Éric Gagnon Poulin

University of North Carolina at Chapel Hill

\begin{abstract}
With the adoption of the "Act to combat poverty and social exclusion" (Act II2) in 2002, Québec had to present three action plans "[...] to guide the Government and Québec society as a whole toward a process of planning and implementing actions to combat poverty and counter social exclusion and strive toward a poverty-free society" (Québec 2002, 2). To achieve this important goal, one of the state's strategies has been to reinforce already existing employment incentives for people considered "fit" for work and promote a more flexible workforce. This article questions the "worth" of unemployed welfare recipients "without limited capacity" for employment in the current neoliberal labour market. This research demonstrates that their "value" is directly linked to their ability to work and productivity in the state discourse on the fight against poverty, influencing thereafter the popular understanding of this polysemous socioeconomic phenomenon. Mainly by analyzing the three action plans to combat poverty and interviewing informants enrolled in employment incentives in the area of Chaudière-Appalaches, this project also underlines how the workfare model collaborates in the reproduction of poverty and the proliferation of precarious jobs in our globalized economies.
\end{abstract}

Keywords: poverty; welfare; state discourse; Québec; neoliberalism; inequality

Résumé: Avec l'adoption de la Loi visant à lutter contre la pauvreté et l'exclusion sociale (Art. II2) en 2002, le Gouvernement du Québec a dû présenter trois plans d'action «[...] pour guider le Gouvernement et la société du Québec dans son ensemble vers un processus de planification et de mise en œuvre d'actions visant à combattre la pauvreté et l'exclusion sociale et à tendre vers une société sans pauvreté » (Québec 2002, 2). Pour atteindre ce but important, l'une des stratégies de l'État a été de renforcer les incitations à l'emploi existantes pour les personnes considérées comme «aptes» au travail et promouvoir une main-d'œuvre plus flexible. Cet article remet en cause la «valeur» des 
bénéficiaires de l'aide sociale au chômage «sans capacité limitée» à l'emploi sur le marché du travail néolibéral actuel. Cette recherche démontre que leur «valeur» est directement liée à leur capacité de travail et à leur productivité dans le discours étatique sur la lutte contre la pauvreté, influençant par la suite la compréhension populaire de ce phénomène socio-économique polysémique. En analysant principalement les trois plans d'action de lutte contre la pauvreté et en interrogeant des informateurs inscrits à des mesures d'incitation à l'emploi dans la région de Chaudière-Appalaches, ce projet souligne également comment le modèle du workfare («travailler pour le bien-être») contribue à la reproduction de la pauvreté et à la prolifération des emplois précaires dans nos économies mondialisées.

Mots-clés: pauvreté; aide sociale; discours de l'État; Québec; néoliberalisme; inégalité

\section{Introduction}

$\mathrm{I}_{\text {pauvreté }}^{\text {fter a long-popular mobilive for a Québec Without Poverty) at the end of the I990s, }}$ the National Assembly of Québec unanimously adopted An Act to combat poverty and social exclusion, "[...] to guide the Government and Québec society as a whole towards a process of planning and implementing actions to combat poverty and counter social exclusion and strive towards a poverty-free society" (Québec 2002, 2). It states that under the Charter of Rights and Freedoms, every human being has the right to live with dignity and respect, and "[...] poverty and social exclusion may constitute constraints for the protection and enforcement of this human dignity" (Québec 2002, 5). To achieve this important goal, one supposes that the state would review its methods to combat poverty; that is, the whole workfare model that was implemented in the last four and a half decades, following the increasing influence of the neoliberal ideology. Since then, activation policies resulting from that model were reinforced by new employment incentives for people considered "fit" for work as "the most effective way" out of poverty. These unemployed welfare recipients then became agents of their own emancipation by participating in the labour market. Nowadays, Québec's welfare policies consolidate three welfare categories: Recipients I) without limited capacity, 2) with temporally limited capacity, and 3) with severely limited capacity for employment. We will see that this situation makes individuals of the first and second category responsible for their own socioeconomic conditions, without considering structural mechanisms that 
could reduce poverty, such as the redistribution of wealth or by regulating the labour market; this, added to the rise in inequalities and already existing systemic exclusion based on class, gender or ethnic origins, among others.

This article questions the "value" of unemployed welfare recipients "without limited capacity" for work in the current neoliberal labour market. Here, the notion of "value" or "worth" is related to the recipient's "merit" from the state's point of view. In other words, whether they "deserve" welfare assistance from the state or not. Firstly, I address the concept of neoliberalism as a class domination project (Cooper and Whyte 2017; Fraser 2016; Harvey 2005) that is constantly changing through time, places, and contexts. I will focus on the corporatization of the state and its services (Nonini in Kapferer 2018), such as social assistance, and how the concept is tied to austerity policies and the workfare model itself; positioned between state and market (Brodkin and Larsen in Brodkin and Marston 2013, 60). Corporations operating in the global arena are reducing the sovereignty of nation-states, whose political and socio-economic interests are subordinated to economic corporate demands (Kapferer 20I8, IO-II). Essentially various corporate practices invade and overtake both official state discourses and practices, as is the case with the Social Assistance Programs. This research demonstrates that the worth of welfare recipients in the state neoliberal discourse is directly linked to their ability to work and productivity, influencing thereafter the popular understanding of this polysemous socioeconomic phenomenon.

It is also about the construction and evolution of the official discourse on poverty, the shift from welfare to workfare, and their impacts on the people experiencing poverty. As Lipsky simply explains it: "It is commonly understood that the key to a successful communications strategy is to continually repeat messages and themes. The conservative critique of the welfare state has been promoted successfully in this way" (Lipsky in Brodkin and Marston 2013, 52). Once deconstructed, the narrative about the "deserving" and "non-deserving" welfare recipients reveals the power relations within the social hierarchy. To cite Arturo Escobar: "[d]iscourse is not the expression of thought; it is a practice, with conditions, rules, and historical transformations" (Escobar 1995, 226). For Michel Foucault, "[d]iscursive practices are characterised by the division of a field of objects, by defining a legitimate perspective on the subject of knowledge, by setting standards for the elaboration of concepts and theories. Each of them therefore presupposes a set of rules that govern exclusions and choices" (Foucault 1994, II08). ${ }^{2}$ As a result, the use of arbitrary categories in the welfare programs creates inclusion and exclusion, worthiness, and unworthiness. 
Consequently, the dialogue around social inclusion is careful to use vocabulary that recognises citizens' agency and "potential" to facilitate their individual DIY projects, to manage the institutional risks to which they are subjected, and thereby facilitate their own improvement. [...]

The realisation of potential is thus fulfilled in paid labour, with economic prosperity (through employment) equated with success, and conversely then, failure with poverty (Smith-Carrier and Lawlor 20I6, II2).

This self-management scheme, together with the repetitive nature of the workfare narrative in the last four and a half decades, has changed the imagining of poverty and its potential solutions—-speeches have created realities.

After explaining my research method, I provide a brief historical context on the transition from welfare to workfare in Québec. Then, I examine the state discourses from official publications, mainly the three Government Action Plans to combat poverty and social exclusion in a context of austerity. Finally, I present a discussion on the impact of the workfare discourse and policies on socialassistance recipients.

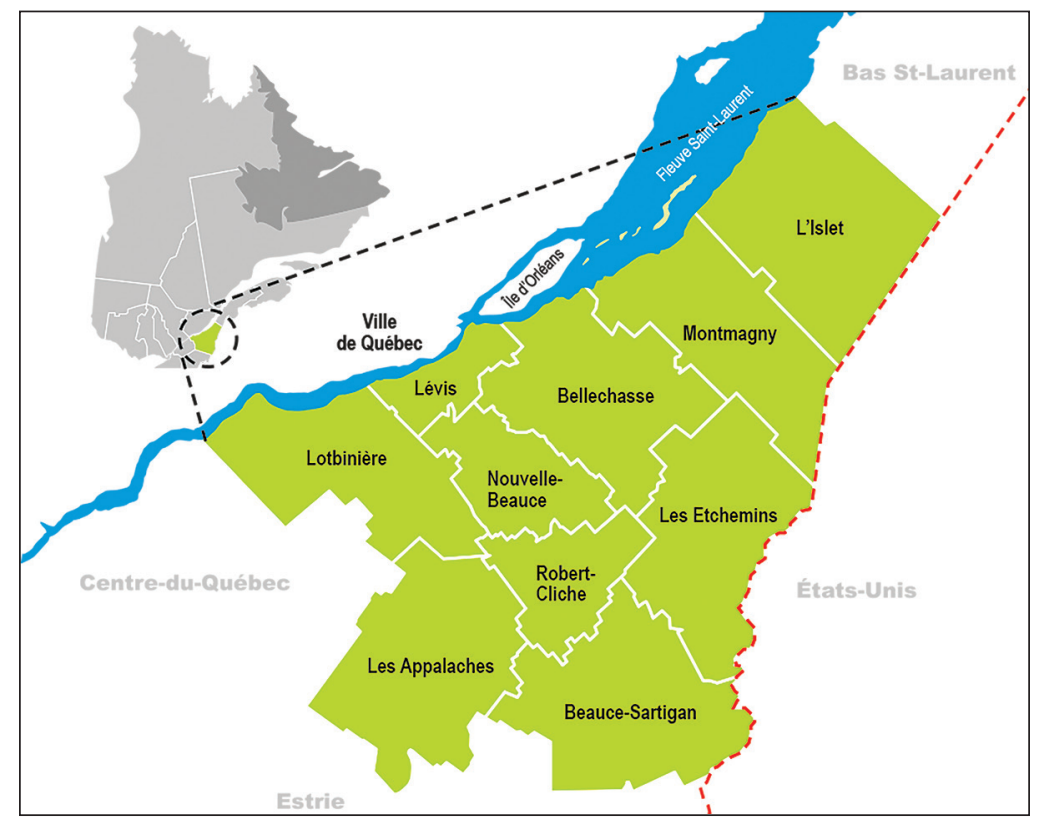

Figure 1: Map of Chaudière-Appalaches, Québec, Canada

Note: The region is divided into 10 regional county municipalities (RCMs) over an area of $15,074 \mathrm{~km}^{2}$, mainly in rural areas but also in urban sectors, such as Lévis, Sainte-Marie and Saint-Georges, with a total population of 421,832.

(Source: batirmaregion.ca, Zonart 2010) 


\section{Methodology}

I first started this research project by analyzing the neoliberal elements of the state discourse on poverty and social exclusion, through official publications and statistics, especially from the three Government Action Plans to reduce poverty (2004-09; 2010-I5; 2017-23), required by the Act to combat poverty and social exclusion (2002). In a context of austerity, especially from 20I4, identifying neoliberal narratives helped gain an understanding of the state's vision on poverty and how "poverty reduction" initiatives are thought out, planned, and implemented. Apparently, the government of Québec had no other choice but to reduce the budgets of public services, including education, health, and social services, public housing, and social assistance. According to Cooper and Whyte:

The sophistication of the austerity narrative, then, is that it enables a kind of smash and grab politics to be supported by a deeply moral and ideological set of principles [...] ; a narrative that brings us all together around a common sense: we maxed out our credit card; we are all in this together; and we all stand to gain after the dust has cleared" (Cooper and Whyte 20I7, 22).

Austerity narrative is one of the tools of the corporate state, just like the workfare model, which is understood as: "[...] a set of communication practises that reflect a particular way of thinking" (Dobson and Knezevic 20I7, 783). One of the ways to save public spending on social assistance would have been to lift people out of poverty by assuring better working conditions, raising the minimum wage, and regulating the labour market to guarantee a basic standard of living that is above the low-income line, at the very least, and then helping people to leave social assistance for good. However, this has not been the state's strategy. Instead, like in the United States and many European countries (especially after the 2007-08 economic crisis), governments kept promoting the workfare model by restricting access to social assistance for people considered "fit" for work. In Québec, it meant reaching the lowest assistance rate since 1976 (5.6 percent, MTESS 20I8, I), and it kept going down until the COVID-I9 pandemic.

Positioned between state and market, then, workfare policies raise politically difficult questions about who deserves state support, who should be excused from work, and what kinds of work make a social contribution. More broadly, workfare raises questions, if only implicitly, about what constitutes fairness in the distribution of both welfare and 
work, what role the state should take in assuring jobs for those who want them, and what distinguishes work from exploitation (Brodkin and Larsen in Brodkin and Marston 2013, 60).

Examining the state discourse on poverty exposes the social hierarchy in broad daylight and shows their role "[...] in perpetuating the neoliberal order by reinforcing the tenets of neoliberal ideology-individual responsibility and primacy of market economy" (Dobson and Knezevic 20I7, 783).

This research also addresses the consequences of the state discourse on poverty for the most concerned; that is, how welfare recipients are impacted by the workfare narrative and public policies that are related it. To conduct this research, I recruited informants in the administrative area of ChaudièreAppalaches, situated in the centre south of Québec (Figure I), for various reasons. First, in 20I4, I was involved in an awareness campaign on poverty in the area. I had the opportunity to observe different regional socioeconomic realities and to work with people living in poverty. This experience, with the demography, regional inequalities, and distribution between rural and urban areas that characterize the province, and having lived there for the previous ten years, made Chaudière-Appalaches an excellent fieldwork for my investigation. The region contains ten regional county municipalities (RCMs) over an area of $15,074 \mathrm{~km}^{2}$, mainly in rural areas, but also in urban sectors such as Lévis, Sainte-Marie and Saint-Georges and has a total population of 428,6I8 (ISQ 20I9). A large part of the territory is extremely vulnerable to poverty, especially in the southeast, where one finds many devitalized communities left with very few public or private services.

I conducted this qualitative research between 2014 and 20I7. To highlight the impacts of the public discourse on their social participation, I recruited 43 participants, mainly people who had lived or were living below the lowincome line (approximately under \$18,000 a year), and who had received social assistance benefits. Inspired by the ability of respondent-driven sampling to provide better access to the so-called "hidden populations" (Heckathorn 1997), I began by going to the local roundtables working on the fight against poverty ${ }^{3}$ to explain the foundations and objectives of this research. There, the people interested (wave 0 , or "germs") could suggest to me members of their network or community (wave I). I also asked the people I recruited and interviewed to refer other people around them who met the selection criteria (wave 2), so that 
subsequent waves would be independent of wave 0 , prompting individuals who would not have cooperated if approached directly and going beyond my own network (Heckathorn 1997, 197). The initial objective was to represent different regional realities through a diverse sample. These semi-structured interviews and ethnographic observations sought to : (I) appreciate how welfare recipients self-identify with the poverty label; (2) measure the impact of the workfare discourses on these individuals; and, (3) identify the forms of emancipation and resistance or passivity and subjugation. Finally, I also interviewed numerous professionals at local and regional round tables, and advocacy and communitybased organisations who were involved in the fight against poverty.

\section{On Meritocracy: From Welfare to Workfare}

The corporatization of the state and its services, austerity, and welfare policies are not new to the academic discussion, but a few key moments in recent history marked an amplification of these neoliberal tendencies in various "western" economies. As mentioned in the introduction, neoliberalism has "evolved" through time, places and contexts. Interestingly, Cahill and Konings remind us that workfare policies preexisted our neoliberal era and had pretty much disappeared after WWII, but came back in force in the I970s:

Workfare of course has historical antecedents, such as Britain's nineteenthcentury Poor Laws and the way they made the workhouse the sine qua none of public assistance. But it was an approach that seemed to have been largely eradicated during the early postwar period. President Nixon was one of the first to use the term "workfare," in the Context of his programme to embed work requirements into the receipt of federally funded welfare (Peck 200I: 90). Reagan also facilitated workfaretype programmes through the 198I Omnibus Budget Reconciliation Act, which made eligibility for welfare more difficult [...] (Cahill and Konings 2017, 87).

In 1963, Québec was a pioneer in the conception of the welfare state in the province and also influenced Canadian policies (that is, Canada Assistance Plan, 1966), especially with the recommendations of the Boucher Report (Boucher 1963). The latter admitted the fundamental right to social assistance, "[...] the principle that every person in need is entitled to assistance from the state, regardless of the immediate or remote cause of this need" (Fortin I988, 2I). 
Despite these good, inclusive intentions, since the adoption of the first Social Assistance Act in 1969, elements of the text paved the way for future reforms based on a counterpart logic, as Olivier Ducharme notes:

Québec's social assistance system has emerged as a hybrid model that grants, on the one hand, an unconditional right to financial protection, but on the other hand, limits this right by allocating insufficient benefits to guarantee the minimum living conditions for the recipients. The authorities were afraid at the time, and still are, that by providing a more generous support, it would discourage the unemployed from looking for work [...]. Low benefits thus concealed an incentive to work and a state commitment to do everything possible to discourage citizens from exercising their right to social assistance. (Ducharme 2018, 68)

In Québec, the peak of stable jobs and wage compensations was reached by 1976, "[...] before it started to decline. At the same time, atypical, and very often precarious, employment grew significantly" (Boucher and Noiseux 2018, II9). By the mid-I970s, along with several economic slowdowns, the promotion of employability became stronger, following the American workfare drift, "[...] as part of the backlash against the progressive movements of the previous decade [...]" (Wacquant 2009a, 43). The state was yet to be managed like a large enterprise; reforms were thus to be made in the names of "financial responsibility" and "good governance:"

The result has been the rise of precarious employment, inconsistent access to public benefits accompanied by increased surveillance, and a growing reliance on financial services and debt. Under these circumstances, welfare has been transformed in qualitative ways: it is not simply that welfare benefits have been reduced, the welfare state has also become thoroughly imbricated with the restructured operations of the capitalist economy at large. This is evident in the growing reliance on "activation" policies (Cahill and Konings 2017, 22).

During the same decade and the one after, at the federal level, the Canadian government implemented its own activation policies by restricting access to unemployment insurance through four reforms and by reducing federal transfers to the provinces that were meant to support the Social Assistance Programs and the education and health systems, among others (Boucher and Noiseux 2018, I26-27). It is important to take the federal historical context into account because provinces depend on certain federal programs, like unemployment insurance and transfers to help finance their own programs. 
Thus, the activation model has not only been a response to the growth of government spending, especially in the context of high unemployment. Above all, it involved ending the reference to the right to a decent income and replacing this right with a discourse of empowerment and autonomy through work (Boucher and Noiseux 2018, I28 my translation).

This way of managing government spending, both at the federal and provincial levels, marked the first steps of the corporatization of the state in Canada.

Back on the provincial scene, the year 1988 brought drastic changes towards a workfare state when the government of Québec adopted the Act respecting income security, requiring welfare recipients under the age of 30 to demonstrate that they were actively seeking work or planning to return to school or participate in employment programs; otherwise, their benefits would be reduced. These measures were gradually applied to all welfare recipients considered "employable." "In 1988, when the law was adopted, it was at that precise moment that categories were implemented. They started to use the notions of 'fit' and 'unfit'," explains Serge Petitclerc, political analyst and spokesperson of the Collectif pour un Québec sans pauvreté, whom I interviewed during my fieldwork. In 1998, the Government of Québec adopted the Act respecting income support, two years after the implementation of the US Personal Responsibility and Work Opportunity Reconciliation Act (PRWORA): “ $[. .$.$] a pioneering bill which transformed welfare provision from being an$ entitlement of citizenship into something one only receives on the condition of performing work and other activity tests" (Cahill and Konings 2017, 47). Somehow inspired by its neighbouring country, Québec's Act respecting income support strengthened employment incentives and confirmed its meritocratic orientation by reinforcing welfare categories, as the introduction mentions, which also meant " $[. .$.$] the conversion of the right to 'welfare' into the obligation$ of 'workfare', designed to dramatize and enforce the work ethic at the bottom of employment ladder" (Wacquant 2009a, 43). Those reforms led to dividing welfare assistance into two programs: Social Assistance, for recipients "without" and "with temporary limited capacity" for employment; and Social Solidarity, for recipients "with severely limited capacity" for employment. Both came with a set of strict rules and requirements that kept increasing through time. The problem, according to Petitclerc, "[...] is that the notion of 'capacity' is related to a medical report, not to the assessment of a person's actual abilities, which is completely different." It is not far from Foucault's concept of "psychiatrization" or "medicalization" of everyday life that "[...] if we examine it closely, it 
would perhaps reveal the invisible power [relations]" (Foucault 1994, IIOO). Furthermore, categorization tends to make individuals responsible for their own success or failure, a scheme that influences both public policies and the popular understanding of poverty as a broader social phenomenon, as Wacquant illustrates with the US workfare:

The American state is the prototype of the "residual welfare state" to the extent that it offers support only in response to the cumulative failures of the labour market and the family, by intervening on a case-by-case basis through programmes strictly reserved for vulnerable categories that are deemed "worthy" [...]. Its official clientele is thus composed of "dependents" from working-class backgrounds, low-pay workers, the unemployed, and families of colour, who have no influence upon the political system and, by the same token, no means of protecting their meager prerogatives. (Wacquant 2009a, 46)

In addition, all these reforms came with new, intrusive bureaucratic formalities "[...] with the aim of discouraging them or striking them off the recipient rolls (be it only temporarily)" (Wacquant 2009a, 50). These reforms based on the workfare model will keep increasing in the coming years and will be reflected in the following Government Action Plans required by the first North American Act to combat poverty and social exclusion, further to the 2007-08 economic crisis, and even more after the election of the Liberal government of Philippe Couillard in 2014 .

\section{The Government Action Plans to Combat Poverty}

In Québec (population 8,484,965, ISQ 2019), more than 743,000 people (CEPE 2020, I2) live below the low-income line (LIL), based on the Market Basket Measure (MBM). The MBM is "[...] based on the cost of a specific basket of goods and services representing a modest, basic standard of living. It includes the costs of food, clothing, footwear, transportation, shelter and other expenses" (Statistics Canada 2016), adapted to regional realities and household composition. From the MBM, the LIL goes from \$17,394 to \$17,720 (CEPE 2020, I9) for a person living alone.

In the province of Québec, the Ministère du Travail, de l'Emploi et de la Solidarité sociale (Department of Labor Employment and Social Solidarity, MTESS) is the main authority representing the government's position on poverty and social exclusion. The Department is also responsible for the Act 
to combat poverty and social exclusion (Act II2) and its action plans to achieve the law's objectives. Its mission is to contribute "[...] to the social development and economic prosperity of Québec" (MTESS 2020). The composition of the Department's name and putting "social development" and "economic prosperity" together in its mission statement imply that one does not go without the other, although economic prosperity must come first to ensure and promote social solidarity. So, without questioning the actual political economy, the Department is clear about this in its publications: social solidarity is only possible through economic growth and employment, regardless of the working conditions.

After the adoption of Act II2, a first Government action plan appeared in 2004. In his introduction, Cabinet Minister Claude Béchard wrote of the government's commitment to achieving the objectives of the Act: "[...] to progressively make Québec [by 2013], one of the industrialized nations having the least number of people living in poverty, according to recognised methods for making international comparisons [...]" (MESSF 2004, 8). The first plan failed to achieve its main goal, which was postponed to the second plan and, then, to the third one.

From the Minister's point of view, achieving that goal was only possible by respecting two principles: "[...] economic security and social inclusion through employment, and increased protection for people with significant employment limitations" (MESSF 2004, 8). The first principle implies that full employment would lead to a more just and inclusive society; the second reinforces the meritocratic classification of welfare recipients, without considering the likely increase of social inequalities and the proliferation of precarious jobs. For instance, I6.7 percent of Québec's working population had an atypical job in 1976 compared to 35.6 percent in 2019 (Boucher and Noiseux 2018, I2O; ISQ 2020). The document clearly states the goals from the very beginning: "Stressing the value of work by providing employment incentives and support for low-income earners is the cornerstone of this Action Plan" (MESSF 2004, 8). In practice, it means forcing the unemployed and social-assistance recipients who are "fit" for work to integrate into the labour market, without ever questioning the actual labour market. This way, the state is claiming to resolve the "problem of poverty" (through employment):

The government is foregrounded as the agent that will 'lift people out of poverty, although the individual, nearly stripped of agency, is assumed to have ultimate responsibility to obtain the skills, education and willingness necessary to exit poverty and enter the realm of the (venerable, employed) 
socially included. Social inclusion here is recurrently linked to economic inclusion; the adoption of the appropriate models of action that conform to neoliberal rationalities (Smith-Carrier and Lawlor 2016, I2I).

Upon review, the then Minister (Sam Hamad) argued that "[...] employment remains one of the most effective ways to fight against poverty [...]" (MESS 20IOb, 7). The report especially emphasizes the increase in the minimum wage from $\$ 9$ to $\$ 9.50$ an hour, as a concrete action against poverty, which, according to the review, will "[...] enable workers, in general, to obtain sufficient income to cover their basic needs" (MESS 20I0b, 7). Indeed, workers whose income is the result of a full-time job paid at the minimum wage and working all year long generally have disposable incomes above the low-income line. However, the main problem is that minimum-wage jobs are often the most precarious and part-time, which the same report recognises: "On average, people on the minimum wage or less worked 25 hours a week" (MESS 20Iob, II), so they "generally" do not cover their basic needs. In fact, they were far from it, earning only \$12,350 a year before tax (2009). "Thus, thanks to a less universal and more targeted employment policy, the state, with a whole continuum of measures aimed at specific 'clienteles,' to use their administrative jargon, also contributes to the proliferation of atypical employment and poverty of the people who take these up these jobs" (Boucher and Noiseux 2018, I45).

In the second Action plan, former premier Jean Charest addressed the issue of redistribution of wealth: "In keeping with our values of solidarity and humanism and our cherished principles of social justice and the redistribution of wealth, Québec has made choices to ensure the well-being of all its citizens" (MESS 20IOa, 5). On the field, social inequalities have increased since the late I97Os, and governments have contributed to the problem by important business and high income-tax reductions, among others:

Between 1997 and 20II, the average purchasing power in the richest quintile of the population has improved with a value above the average income of the poorest quintile. [...] In the same period and using the same data, the average tax paid by all households in the richest quintile decreased from $26 \%$ to $22 \%$ of their average total income. (Labrie 20I4, I)

In other words, from 1997 to 20II, it would have been possible to double the income of the poorest quintile, allowing the majority of these people to have incomes above the low-income line, without taking one cent from the richest quintile. 
Again, the counterpart logic is central to this second action plan, without ever questioning the increasingly deregulated job market: "Training and access to employment remain two core premises in combating poverty and social exclusion" (MESS 20I0a, 7). This means that the unemployed has to be more "flexible" and adapt to the market, as explained by Lambert and Henly:

Varying work hours to fit demand, making last-minute changes to work schedules, and reducing work hours during seasons of low demand are made all the easier if one hires and maintains a workforce that can accommodate fluctuating hours. One strategy frontline managers employ to meet hour targets is to give preference to workers with "open availability"; that is, employees who can work varying and unpredictable work hours. [...]

Workers whose availability is limited by family and other personal responsibilities are at the heightened risk of low work hours and, in turn, of not meeting the hour requirements defined in public policy (Lambert and Henly in Brodkin and Marston 2013, 76).

In the third Action Plan 2017-23, the state follows the same pattern and goes even further with the application of Bill 70, now Act 25, forcing first-time welfare recipients considered "fit" for work to enrol in Objectif emploi, an employment incentive, or possibly see their social assistance reduced from \$633 to \$409 a month (Gazette officielle du Québec, chapter A-I3.I.I). This in total contradiction with the Act to combat poverty and social exclusion (article 15.2), by introducing "[...] the minimum benefit principle, a threshold below which benefits cannot be reduced by reason of the application of administrative penalties [...]" (Québec 2002).

These reforms have a profound impact on the power relations between employers and employees, as Charon describes very well:

Through these punitive policies, the state is not only arbitrating the relationship between employers and the workforce, or even forcing beneficiaries to return to work; it directly organises their disciplinarisation within the wider social assistance system, which involves non-profit organisations offering employability development activities prescribed by a state official, or private companies, commercial or not, who receive wage subsidies to hire social assistance recipients (Charron 2019, 43).

Moreover, "[t]he notion of "suitable employment" is to be defined on a discretionary basis by the Minister himself" (Boucher and Noiseux 20I8, I44). So, it is 
legitimate to question the real intentions behind such reforms. Will Objectif emploi guarantee decent working conditions? Will participants earn enough money to cover their basic needs? "Thus, despite an envelope of \$5 million planned to increase the benefits of those who will accept the integration plan [...], the Minister announced at the same time that he intended to reduce the costs associated with social assistance by $\$ 50$ million" (Boucher and Noiseux 2018, I44).

This third action plan, then, reinforces the "contract of reciprocity" (Morel 2002) and runs counter to the main principles of Act II2 regarding the living conditions of recipients who are considered "fit" for work, who will only cover 55 percent of their basic needs (according to the MBM) by the end of the plan (2023), a threshold that the government chose not to exceed. Besides, the idea that benefits beyond 55 percent of the MBM do not encourage people to return to work seems rather more ideological than scientific. Indeed, coupling drastic incentives with benefit reductions may even encourage the reproduction of systemic poverty. More often than not, the trajectory of precarious workers will tend to be circular; from an unstable job to employment insurance (if eligible), to social assistance, and so on. In contrast, with higher benefits and less coercion, as the Norwegian model demonstrates, recipients generally have more time for training and a better chance of finding as well as wanting a suitable and stable job (McKowen 2020). They can also stay in better physical and mental health, preventing them from falling into what my informants call the "spiral of poverty."

In theory, official government publications reflect no differences in the "value" of welfare recipients on the basis of gender, class, ethnicity, religion, or identity, but important differences appear between a person who has the "capacity" to work and one who does not. On the one hand, the "worth" of the individual who cannot "officially" work is unaffected, with a medical report that the state recognizes confirming the person does not have the physical or the mental capacity to work. From the state's point of view, that person deserves social protection and no pressure is put on them to reintegrate into the labour market. From this specific angle, they are "worthy." Unfortunately, this often contributes to their exclusion, because of the space that employment occupies in society, often seen as the only way of participating in social life. On the other hand, the value of the unemployed, who have the "capacity" to work 
or are unable to obtain official recognition of their "severe limited capacity,"4 is significantly reduced, and they have little or no access to social assistance from the state if they do not comply with the program requirements.

Although, in practice, ethnic and gender-based discrimination, for instance, is a documented reality in Québec. Indeed, on average, women earn \$2.55/hour less than men, 60 percent of the minimum wage jobs are occupied by women, 33 percent of single mothers live below the low-income line, and 36 percent of First Nation women live in poverty (Observatoire de la pauvreté et des inégalités au Québec 20I5, I-2). Also, a job seeker with a "foreign" name, such as Abdellah Hafid, is half as likely to be selected for a job interview, than someone with a common Québec name such as Marc-Olivier Tremblay (Desrosiers 2019). These statistics are just a few examples of endemic inequality. Thereby, it has to be underlined that the corporatization of the state does greater harm to people who are already suffering from systemic discrimination and exclusion.

Adding to the proliferation of precarious jobs is the application (or simple reinforcement) of drastic austerity measures in "industrialized" economies after the 2007-08 global financial crisis, and this in the name of budgetary discipline.

However, in being able to see the real aims and desires of the political elite, and how those aims and desires are connected intimately to the interests of the financial and business elites, we begin to understand austerity as little more than a cruel and violent strategy of class domination" (Cooper and Whyte 20I7, 24).

The consequences of austerity are important, especially for the middle class; even more so for less affluent and marginalized populations. "As the state withdraws from welfare provision and diminishes its role in arenas such as health care, public education, and social services, [...] it leaves larger and larger segments of the population exposed to impoverishment" (Harvey 2005, 76).

The 2016 report of the Institut de recherche et d'informations socio-économiques demonstrates the negative impacts of these measures. Between 2014 and 2016, the Liberal government of Québec imposed budget cuts of 4.024 billion dollars in areas such as education, health care, social services, social assistance, and housing (Nguyen 20I6; IRIS 20I6). "With such decisions the government implies that it is quite possible and socially acceptable to give up on the poorest" (Nguyen 20I6, 7). It is clear that thousands of jobs were lost, public institutions 
registered deficits, programs, and services were amputated or simply suppressed. As Cooper and Whyte put it: "Austerity is a class project that disproportionately targets and affects working class households and communities and, in so doing, protects concentrations of elite wealth and power" (Cooper and Whyte 20I7, II).

\section{Discussion: "Debased," "Devalued," and "Socially Useless"}

The participants interviewed during fieldwork were mainly people who had been welfare recipients and experienced different forms of poverty. How my informants identified themselves with the poverty label varied from one person to another. However, the vast majority pointed out their economic situation as their principal problem, an issue that encourages other problems, such as social exclusion; as if being unemployed and having less money affected their social value, even in the eyes of family and friends, because of the "cost" they can represent:

You almost lose them all, because you are no longer able to follow their lifestyles. Before, [...] I had friends with whom I did all kinds of activities. Being on welfare, we used to see each other from time to time, but they were always paying for me. After a while, my friends stopped seeing me. It is another factor of isolation. [...] For my family, the same thing happened. (participant 9)

Official and public discourses seemed to have an appreciable impact on their social participation, especially for those considered "fit" for work:

The minute people know that you are on social assistance, they have another way of perceiving you, of seeing and acting with you. [...] We are isolated in our residence, in our apartment, in our little corner. (participant 9)

When we introduce ourselves to someone, the first thing we ask is: "What is your name, what do you do?" Well, I'm not doing anything right now. Well, I don't work these days. You become like a no-name in society, you have no value, [...] no more personality. I felt like a mediocre person, [...] excluded from society. (participant 2)

Unemployed and asking for help from the state, you're nothing. All your past disappears. You were not resourceful, you were not an entrepreneur for 20 years, you did not teach. I used to teach, you know! (participant I) 
As David Graeber brilliantly sums it up,

We have become a civilization based on work-not even "productive work" but work as an end and meaning in itself. We have come to believe that men and women who do not work harder than they wish at jobs they do not particularly enjoy are bad people unworthy of love, care, or assistance from their communities" (Graeber 2013, 36-37).

This feeling of unworthiness is unfortunately reflected in the testimonies I collected during fieldwork. Clearly, in addition to social exclusion, many of my informants internalize those negative representations of the unemployed and the welfare recipient, consciously or not, and drive themselves out of social life. Many of them revealed they felt, "debased," "devalued," and "socially useless:"

I'm bipolar, I live in a public residence and I'm on welfare [...] That's not too good. So, I do not talk about my situation much. (participant I9)

Even people on welfare have prejudices towards social assistance. They often think they are "not worthy." They are afraid to talk about it, even if they have good reasons to be on welfare. (participant 9)

Isolation and low self-esteem can be a horrendous combination that can sometimes lead to dark ideas, as this informant illustrates: "I can go on with the money I'm given, but it's like begging. Sometimes you say to yourself that you'd rather be dead" (participant 6). In the UK, a group of applied psychologists decided to document and denounce the impact of the corporatization of the state on mental health: Psychologists Against Austerity. "The group produced a briefing paper that includes five 'austerity ailments' it believes contribute to worsening mental despair. These are: humiliation and shame; instability and insecurity; isolation and loneliness; being trapped or feeling powerless; and fear and distrust" (Cooper and Whyte 2017, 39). For Claudine Gagnon from the Collectif pour un Québec sans pauvreté, the situation "[...] plunges [them] into the shame of their social conditions. We often hear that people living in poverty, and even more people on social assistance, do not deserve to be happy. With those prejudices, we dehumanise them. They are no longer people; they become a concept." What she underlines could be described as a form of moral and cultural hegemony: "[...] it strengthens the social hierarchy, it creates scapegoats and it allows others to promote their place and it justifies social inequalities," says Gagnon, who also participated in this project. Indeed, neoliberalism is: 
" [...] a process that has created the structures and conditions that perpetuate and sustain poverty, while rendering people culpable for the systemic failures that accompany neoliberal restructuring" (Smith-Carrier and Lawlor 2016, I2I).

Despite the way they are negatively seen by a part of society and sometimes themselves, people on welfare do not lack agency. All of my informants receiving social assistance and who considered they had the capacity to work revealed that they wanted to find a job again, but that they wanted to be able to make ends meet at the end of the month:

Often, you say to yourself, 'I do not want to be on welfare anymore!' That's why I decided to go to university; to try to get a better job. I will not work at the minimum wage all my life. I want a good job, to be a professional and get out of it for good" (participant 7 ).

However, after being on social assistance, it often takes a long time before they finally get a better job and improve their socioeconomic conditions, partly because being away from the labour market and having experienced social assistance is difficult to justify to most employers. They must use and develop their agency to survive with what they have.

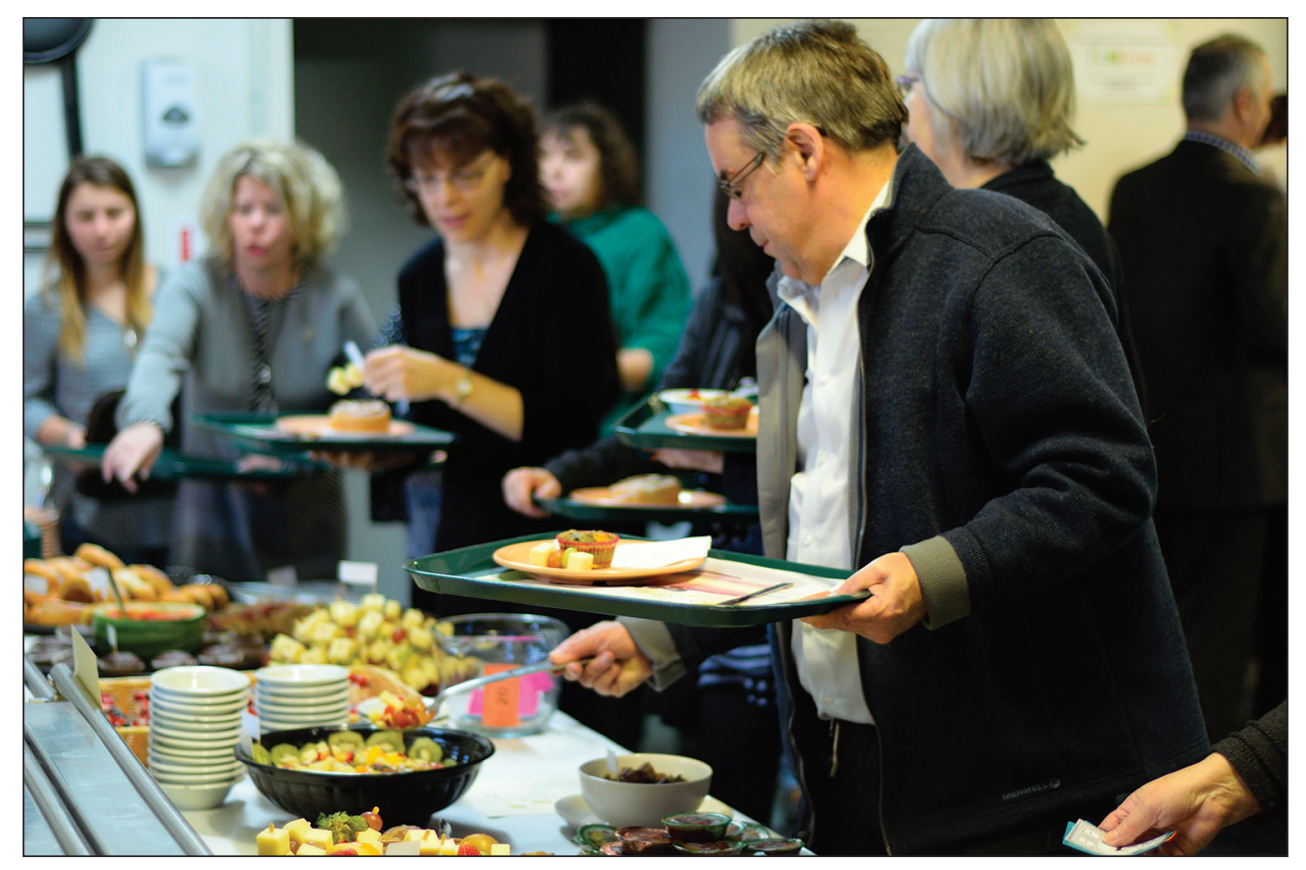

Photo 1: A food bank in Lévis, Québec, Canada.

Note: "The government does practically nothing. We leave that in the hands of community organisations and citizens to provide food aid, collective kitchens, awareness-raising activities, meetings to discuss our rights, etc. [...] Without these groups, we would be in trouble" (participant 9).

(Source: Gagnon Poulin and Fortin 2015) 
One of the responses I observed during fieldwork was committing acts of individual resistance and, occasionally, organised resistance (Scott 1992). Individual resistance often involves not respecting the program rules, such as having illiquid or liquid assets beyond the program's limit, sharing housing, receiving donations or income from work without declaring it. "We have no choice, otherwise we are not able to keep our heads above water" (participant 19). Organised resistance can be expressed legally or illegally. Legally, some of my informants had either joined a rights organisation or participated in such actions as demonstrations, civic outreach activities, or self-help workshops. Illegally, a few became involved in selling contraband tobacco, cannabis, or other drugs. Some participants believe that the current labour market, coupled with the deterioration of social protections, is responsible for the reproduction of such activities. It can also be seen as an alternative for regaining and defending their dignity. This strategy can certainly work in order to make a living and, sometimes, to counter social exclusion through membership in a group or a gang, but only until they get caught. Loïc Wacquant's work on the shift from welfare to workfare and "prisonfare" is interesting with respect to understanding how it can be politically exploited:

The punitive slant of recent shifts in both welfare and justice policies points to a broader reconstruction of the state coupling restrictive "workfare" and expansive "prisonfare" under a philosophy of moral behaviorism. The paternalist penalization of poverty aims to contain the urban disorders spawned by economic deregulation and to discipline the precarious fractions of the postindustrial working class. Diligent and belligerent programs of "law and order" entailing the enlargement and exaltation of the police, the courts, and the penitentiary have also spread across the First world because they enable political elites to reassert the authority of the state and shore up the deficit of legitimacy officials suffer when they abandon the mission of social and economic protection established during the Fordist-Keynesian era. (Wacquant 2010, 198)

In short, in parallel with the transformations of the political economy was an ideological reorientation from an inclusive welfare philosophy to a meritocratic and categorised workfare model into which the recipient must "fit." They "[...] must at the same time accept to be recognised as poor, admit the control of their private life by social action specialists and show a will 'to succeed' [...]" (Paugam I99I, II4). What if they do not? Still, without complying and identifying with a given category, a person in need will not be able to receive help from the 
state. So, what choice do they have? As pointed out by a few of my informants, we can assume that "[...] there will be more people on the street, more misery, so more social problems and crime, it goes together!" (participant 15)

\section{Conclusion}

To justify the important transformations underlined in this paper, governments "[...] began acting as if social programs were a hindrance to economic growth and financial responsibility" (Rice and J. Prince 2013, II4). Today, the same arguments are used to pursue the corporatization of the state and justify ongoing austerity measures, with a certain popular consent or indifference. We saw that, nowadays, one has to deserve social assistance, "[...] in the sense of a win-win relationship or a counterpart logic: a right (social assistance) is related to a duty (work or other types of activity) for the recipient" (Morel 2002, I0). This research demonstrates that the situation tends to devalue people on welfare, particularly those considered "fit" for work, as they have not fulfilled their part of the "contract of reciprocity" (Morel 2002). This binary notion of "fit" or "unfit" is nothing else but a sociopolitical construction that determines if they deserve assistance from the state or not, if they are deemed "worthy" or "unworthy," which Nancy Fraser addresses in terms of political subjectivation, that is: "[...] the codification by public powers of the status hierarchies that distinguish citizens from subjects, nationals from aliens, entitled workers from dependent scroungers. Available in principle for racialization, status hierarchy, too, is an essential condition for accumulation [...]" (Fraser 2016, 170).

As this article shows, the fight against poverty in Québec has nothing to do with its I96os model. Today, on the one hand, the state invests several million dollars annually to "combat poverty" through its action plans, but on the other hand, it cuts billions each year from the budgets for social protection and public services, essential to the less fortunate. Most certainly, "[c]uts in public services in times of fiscal austerity tend to hit the poorest sections of the populations hardest, exacerbating existing disparities in healthcare and outcomes (Bambra et al. 2016: 169). Similarly, neoliberal restructuring has had a profound impact on educational opportunities and achievements" (Cahill and Konings 20I7, I23); thus, consolidating and worsening socioeconomic disparities. Consequently, is there a true political will to reduce poverty in Québec in this context of austerity? The current model mostly focuses "[...] on the individual duty of the poor to contribute to society by individually deploying meritorious behaviors that will institute them as citizens" (Morel 2002, IO). It is considered their moral 
responsibility to get out of poverty through employment, although in the field, it can be observed that "[...] the new punitive organisation of welfare programs operates in the manner of a labour parole program designed to push its 'beneficiaries' into the subpoverty jobs that have proliferated after the discarding of the Fordist-Keynesian compromise" (Wacquant 2009, 43). As a result, these unstable and low-pay jobs are inexorably creating more poverty and inequalities to an unprecedented level, and the worst has yet to come. As Charron points it out, "[i]t is time to fight against the false neutrality of the activation policies and to demonstrate how the states collaborates, through [its management] of social assistance, to both the restructuration and increase in social inequalities in the XXIe century" (Charron 2019, 46).

This is a significant step backward, knowing that in 1963, the Boucher Report came to this conclusion: "Previously it was thought that if a person was poor, it was their fault. Today, we understand that poverty is often due to economic or social factors over which the individual alone cannot control" (Boucher I963, II8). Lately, the Liberal government of Québec has congratulated itself on having reached the lowest assistance rate since 1976 (5.6 percent, MTESS 20I8, I), awkwardly interpreting this data as a measure of poverty. However, the number of people living below the low-income line has stayed about the same since the adoption of the Act to combat poverty and social exclusion (CEPE 2017). "Clearly, performance measurement may be used in ways that indirectly privilege one set of policy purposes (in this instance, caseload reduction and increased work effort) over others, like improved economic prospects or family well-being" (Brodkin and Marston 2013, 27). Fewer people are on welfare but there are more precarious workers, as all the food banks can corroborate, especially in my fieldwork, where Moisson Beauce noted an increase of 506 percent in food aid from 2006 to 2018 (Moisson Beauce 2018). Another factor that often contributes to their social exclusion: "Suggestions that the poor are unable to budget or cook are forms of symbolic violence that serve to further stigmatise and marginalise those already suffering material deprivation and social exclusion" (Cooper and Whyte 2017, 98).

The corporatization of the state and its services constructed a radical "social contract" that offers the private sector an all-new workforce: thousands of welfare recipients considered employable, pushed back into precarious jobs. "This entailed confronting trade union power, attacking all forms of social solidarity that hindered competitive flexibility [...], dismantling or rolling back the commitments of the welfare state" (Harvey 2005, 23). And for those still on 
social assistance, they must find ways to survive with their small revenues, and sometimes, this means doing so outside of the "legal" economy. Coercion added to the individualization of the causes of poverty has a dividing and demobilizing effect. "Thus, the targeting of benefit claimants can merge with certain forms of racism and ultimately be mobilised to render the most precarious sections of the workforce more compliant and 'flexible'" (Cooper and Whyte 20I7, 22I). The poor worker then blames the assisted poor of not deserving the very little they have, instead of constituting a popular force that could shake the foundations of the neoliberal model.

\section{Éric Gagnon Poulin,} University of North Carolina at Chapel Hill, eric.gagnon.poulin@unc.edu

\section{Funding}

Fonds de recherche du Québec - Société et culture (FRQSC) [2020-B3-271548].

\section{Notes}

- The Collectif pour un Québec sans pauvreté (Collective for a Québec Without Poverty) was then called the Collectif pour une loi sur l'élimination de la pauvreté (Collective for a Law to Eliminate Poverty). It changed its name after the adoption of the Act to combat poverty and social exclusion in 2002.

2 Boucher and Noiseux 2018; Charron 2019; Ducharme 2018; Fortin 1988; Foucault 1994; Labrie 2014; Morel 2002; Nguyen 2016; Paugam 199I; transcriptions from my interviews are my own translations; Turbide 20I5; .

3 Also called "Groupes de réflexion et d'action sur la pauvreté" (Groups of reflection and action on poverty [GRAP]). There is one roundtable or one GRAP by Regional County Municipality (RCM).

${ }_{4}$ To be considered as having a "severely limited capacity" for employment, the applicant must have a physical or mental illness that the state recognizes, which could be complicated by certain health issues, such as fibromyalgia. Some of my informants who were suffering from it were still considered "fit" for work. 


\section{References}

Boucher, J-Émile. 1963. Rapport du comité d'étude sur l'assistance publique. Québec: Gouvernement du Québec.

Boucher, Marie-Pierre, and Yanick Noiseux. 2018. "Austérité, flexibilité et précarité au Québec: la fuite en avant." Labour/Le Travail 8I (Spring): II9-57. https://www.jstor. org/stable/44820627.

Brodkin, Evelyn Z., and Gregory Marston, eds. 20I3. Work and the Welfare State: Street-Level Organizations and Workfare Politics. Georgetown: Georgetown University Press.

Cahill, Damien, and Martijn Konings. 20I7. Neoliberalism. Weinheim: John Wiley \& Sons.

CEPE. 2017. La pauvreté, les inégalités et l'exclusion sociale au Québec: état de la situation 20I6. Québec: Centre d'étude sur la pauvreté et l'exclusion.

—_ 2020. La pauvreté, les inégalités et l'exclusion sociale au Québec: état de la situation 2019. Québec: Centre d'étude sur la pauvreté et l'exclusion.

Charron, Catherine. 2019. “'Tout emploi, quel qu'il soit': l'injonction à l'emploi pour les prestataires d'aide sociale au Québec 1990-2005.” Reflets 25 (I): 30-50. https:// doi.org/I0.7202/I064666ar.

Cooper, Vickie, and David Whyte, eds. 20I7. The Violence of Austerity. London: Pluto Press.

Desrosiers, Éric. 2019. “Le nom, un facteur de discrimination à l'embauche." Le Devoir, I9 June. https://www.ledevoir.com/economie/557033/le-nom-un-facteur-dediscrimination-a-l-embauche (accessed I July 2020).

Dobson, Kathy, and Irena Knezevic. 2017. "'Liking and Sharing' the Stigmatization of Poverty and Social Welfare: Representations of Poverty and Welfare through Internet Memes on Social Media.” Triple C, 777-795. https://doi.org/IO.3I269/triplec.vi5i2.8I5.

Ducharme, Olivier. 20I8. Travaux forcés: chemins détournés de l'aide sociale. Montréal: Écosociété.

Escobar, Arturo. 1995. Encountering Development: The Making and Unmaking of the Third World. Princeton: Princeton University Press.

Fortin, Denis. 1988. Riches contre pauvres, deux poids, deux mesures ou de l'aide sociale aux plus démunis à l'assistance cachée pour les bien-nantis. Québec: Les Éditions Autogestionnaires.

Foucault, Michel. 1994. Dits et Écrits I, I954-I975. Paris: Quarto Gallimard. 
Fraser, Nancy. 2016. "Expropriation and Exploitation in Racialized Capitalism: A Reply to Michael Dawson.” Critical Historical Studies Spring (2016): I63-178. https://doi. org/IO.IO86/6858I4.

Graeber, David. 20I3. Bullshit Jobs. London: Simon \& Schuster.

Harvey, David. 2005. A Brief History of Neoliberalism. Oxford: Oxford University Press.

Heckathorn, Douglas D. 1997. "Respondent-Driven Sampling: A New Approach to the Study of Hidden Populations." Social Problems 44 (2): I74-199. https://academic. oup.com/socpro/article-abstract/44/2/I74/I635494?redirectedFrom=fulltext.

IRIS. 20I6. Observatoire des conséquences des mesures d'austérité au Québec. Montréal: Institut de recherche et d'informations socio-économiques (IRIS). https://austerite.irisrecherche.qc.ca/ (accessed 9 April 20I8).

ISQ. 20I9. Profils statistiques par région et MRC 20I9. Québec: Institut de la statistique du Québec (ISQ). https://www.stat.gouv.qc.ca/statistiques/profils/region_oo/region_oo. htm (accessed I5 May 20I9).

—_ 2020. Taux d'emploi atypique selon diverses caractéristiques, Québec, Ontario et Canada. Québec: Institut de la statistique du Québec (ISQ). https://www.stat.gouv.qc.ca/ statistiques/travail-remuneration/lien-statut-emploi/taux_emploi_atypique.html\#tri_tertr=50040\&tri_sexe=I (accessed 20 June 2020).

Kapferer, Bruce, ed. 20I8. State, Resistance, Transformation: Anthropological Perspectives on the Dynamics of Power in Contemporary Global Realities. Canon Pyon: Sean Kingston Publishing.

Labrie, Vivian. 20I4. La Mesure du panier de consommation et les seuils de faible revenu. Québec: Collectif pour un Québec sans pauvreté.

McKowen, Kelly. 2020. "Substantive Commitments: Reconciling Work Ethics and the Welfare State in Norway." Economic Anthropology 7 (I): I2O-I33. https://doi.org/IO.IOO2/ sea2.I2169.

MESS. 20I0a. Government Action For Solidarity and Social Inclusion 20IO-20I5. Québec: Ministère de l'Emploi et de la Solidarité sociale (MESS).

- 20Iob. Plan d'action gouvernemental en matière de lutte contre la pauvreté et l'exclusion sociale 2004-2009, bilan de la cinquième année. Québec: Ministère de l'Emploi et de la Solidarité sociale (MESS). 
MESSF. 2004. Reconciling Freedom and Social Justice: A Challenge for the Future: Government Action Plan to Combat Poverty and Social Exclusion. Québec: Ministère de l'emploi, de la solidarité sociale et de la famille (MESSF).

Moisson Beauce. 20I8. Évolution du nombre de personnes aidées par mois :2008-20I8. SaintGeorges: Moisson Beauce, document du conseil d'administration.

Morel, Sylvie. 2002. Modèle du workfare ou modèle de l'insertion? La transformation de l'assistance sociale au Canada et au Québec. Ottawa: Condition féminine Canada.

MTESS. 20I8. Rapport statistique sur la clientèle des programmes d'assistance sociale. Québec: Ministère Du Travail, de l'Emploi et de La Solidarité Sociale (MTESS).

——. 2020. Ministère Du Travail, de l'Emploi et de La Solidarité Sociale. https://www.quebec. ca/en/government/ministere/ministere-du-travail-de-lemploi-et-de-la-solidaritesociale/ (accessed I6 July 2020).

Nguyen, Minh. 2016. Bilan de l'observatoire sur les conséquences des mesures d'austérité. Montréal: Institut de recherche et d'informations socio-économiques (IRIS).

Observatoire de la pauvreté et des inégalités au Québec. 20I5. Femmes et Pauvreté. Québec: Collectif pour un Québec sans pauvreté.

Paugam, Serge. 199I. La Disqualification Sociale. Paris: Presses universitaires de France.

Québec. 2002. Act to Combat Poverty and Social Exclusion. Québec: Gouvernement du Québec.

Rice, James J., and Michael J. Prince. 2013. Changing Politics of Canadian Social Policy. Toronto: University of Toronto Press.

Smith-Carrier, Tracy, and Andrea Lawlor. 2016. "Realising Our (Neoliberal) Potential? A Critical Discourse Analysis of the Poverty Reduction Strategy in Ontario, Canada." Critical Social Policy 3I (I): I05-I27. https://doi.org/IO.II77/026IoI83I666625I

Statistics Canada. 20I6. Market Basket Measure (MBM) - National Household Survey (NHS) Dictionary. Ottawa: Statistics Canada. https://wwwi2.statcan.gc.ca/nhs-enm/20II/ ref/dict/popi65-eng.cfm (accessed I8 April 2018).

Wacquant, Loïc. 2010. "Crafting the Neoliberal State: Workfare, Prisonfare, and Social InsecurityI: Crafting the Neoliberal State." Sociological Forum 25 (2): 197-220. https:// doi.org/IO.IIII/j.I573-786I.20I0.0II73.x.

- - 2009. Punishing the Poor: The Neoliberal Government of Social Insecurity. Politics, History, and Culture. Durham: Duke University Press 